\title{
Author Correction: MAD2B acts as a negative regulatory partner of TCF4 on proliferation in human dermal papilla cells
}

\author{
Nanlan $\mathrm{Yu}^{1}$, Zhiqiang Song ${ }^{1}$, Kezhou Zhang ${ }^{2}$ \& Xichuan Yang ${ }^{1}$ \\ Correction to: Scientific Reports https://doi.org/10.1038/s41598-017-10350-w, published online 15 Spetember \\ 2017
}

In the original version of this Article, Nanlan Yu and Zhiqiang Song were omitted as equally contributing authors.

In addition, there was an error in Figure 4, where the $\beta$-catenin results were listed as “-, - " instead of “-, +". The correct Figure 4 now appears in the article.

This Article also contained errors in the Results section under subheading 'MAD2B physically interacts with TCF4 in DPCs'.

"Furthermore, our results confirmed that TCF4 also physically interacted with $\beta$-catenin, an essential component of the canonical Wnt signaling pathway (Fig. 4C)."

now reads:

"Furthermore, our results confirmed that overexpression of $\beta$-catenin, an essential component of the canonical Wnt signaling pathway, does not affect the interaction between MAD2B and TCF4 (Fig. 4C)."

These errors have now been corrected in the PDF and HTML versions of the paper.

(c) (i) Open Access This article is licensed under a Creative Commons Attribution 4.0 International cc. License, which permits use, sharing, adaptation, distribution and reproduction in any medium or format, as long as you give appropriate credit to the original author(s) and the source, provide a link to the Creative Commons license, and indicate if changes were made. The images or other third party material in this article are included in the article's Creative Commons license, unless indicated otherwise in a credit line to the material. If material is not included in the article's Creative Commons license and your intended use is not permitted by statutory regulation or exceeds the permitted use, you will need to obtain permission directly from the copyright holder. To view a copy of this license, visit http://creativecommons.org/licenses/by/4.0/.

(C) The Author(s) 2018

${ }^{1}$ Department of Dermatology, The First Affiliated Hospital of the Third Military Medical University, Chongqing, 400038, China. ${ }^{2}$ Department of Dermatology, The 401st Hospital of Chinese People's Liberation Army, 22 Minjiang Road, Qingdao, 266000, China. Nanlan Yu and Zhiqiang Song contributed equally to this work. Correspondence and requests for materials should be addressed to X.Y. (email: 359570520@qq.com) 